\title{
The Risk Assessment for the Healthcare Waste in the Hospital of Batna City, Algeria
}

\author{
L. Sefouhi, M. Kalla, L. Bahmed, and L. Aouragh
}

\begin{abstract}
Inadequate management of healthcare waste (HCW) is a serious concern in many developing countries due to the risks posed to human health and the environment. Poor management of $\mathrm{HCW}$ exposes health care workers, waste handlers and the community to different risks as : infections, toxic effects and injuries. Risk Management is the identification, assessment, and prioritization of risks. In Algeria, many efforts have been made by the government authorities in order to better manage the waste from healthcare facilities. However most healthcare facilities do not comply with the principles stated in Algerian legislation.

In the hospital of Batna city, a total about $1114 \mathrm{Kg}$ of risky healthcare waste (RHCW) are produced each day. By using Preliminary Hazard Analysis (PHA) which is an assessment tools, our focus in this paper is to identify and study health risks that may occur due to the existence of hazardous elements in healthcare waste, to identify treatment modalities tailored to each adverse event and to characterize and prioritize these adverse event in terms of occurrence and severity scenario.
\end{abstract}

Index Terms-Management, preliminary hazard analysis, RHCW, risk assessment.

\section{INTRODUCTION}

Poor management of Health Care Waste (HCW) can cause serious diseases for healthcare personnel, who are responsible for waste disposal, patients and the general population. Some types of HCW represent a higher risk to health than others. Approximate $15-25 \%$ (by weight) of $\mathrm{HCW}$ is considered infectious [1].

Risk assessment is identification of hazards and the analysis and evaluation of risk related to with exposure to those hazards. As an aid to clearly defining the risk for risk assessment few fundamental are often useful, such as what might go wrong? What is the probability and consequence of wrong occurrence? The methods include Preliminary Hazard or Risk Analysis (PHA/PRA), Failure Modes and Effects Analysis (FMEA) Hazards and Operability Study (HAZOPs), Fault Tree Analysis (FTA) and others are used to identify, quantify, and mitigate risk..

Health Care Waste (HCW) in each hospital should be studied separately, since medical waste generation and composition depends on the number and type of departments/laboratories at each hospital, number of external patients and number of occupied beds [2]. Our study focused on risky healthcare waste (RHCW) in the hospital of Batna city. The average rate of RHCW generation was $1.75 \mathrm{~kg} / \mathrm{bed} /$ day which is higher than the national value of $0.72 \mathrm{~kg} / \mathrm{bed} / \mathrm{day}$. Inconsistencies occur in

Manuscript recevied March 25, 2013; revised May 8, 2013.

The authors are with LRNAT. University of Hadj Lakhdar, Batna, Algeria (e-mail : lsefouhi@yahoo.fr). the management options for RHCW in the Hospital of Batna. Lack of knowledge on the pertinent legislation by health workers has contributed to non-conformity instances. Many injuries and infections were recorded, when carrying RHCW from point of generation to the HCW disposal. Preliminary Hazard Analysis (PHA) was applied in this study. PHA has been widely applied in industrial risks, our study attempted to apply for risk related to healthcare waste.

A preliminary hazard analysis is conducted to identify potential hazards and prioritize them according to: the likelihood of an accident or injury being caused by the hazard; and the severity of the injury, illness, or property damage that could result if the hazard caused an accident. This tool analysis is based on applying prior experience or knowledge of hazard to identify future hazards, hazardous situation and then risk assessment of RHCW.

\section{BASIC RISKS ASSOCIATED WITH THE POOR MANAGEMENT OF HEALTHCARE WASTE}

Wastes in a healthcare facility cover a diverse range of materials that can be divided into two broad categories: Health care general waste (or non-hazardous waste) and Healthcare risk waste (hazardous waste). Medical waste contains a large component of domestic type and a smaller component of hazardous waste [3]. General waste poses no additional risk of injury or infection to staff, to patients, to visitors, or to the community at large. It is similar in composition to household trash. Risky Healthcare waste (RHCW) consists of several different sub categories such as: Infectious waste, Anatomic wastes, Sharps waste, Pharmaceutical \& chemical waste, Human anatomical waste and Radioactive waste (Fig. 1). Of the total amount of waste generated by healthcare activities, about $80 \%$ is general waste comparable to domestic waste. The remaining $20 \%$ is considered hazardous material that may be infectious, toxic or radioactive and approximate percentage of waste type per total waste in primary health care centers is represented in Fig. 2 [4].

The term "infectious" is used differently in the medical and waste management areas. In general, medical professionals consider patient excretions as infectious, but the views of waste management professionals vary, depending on the country [5]. In some countries, e.g., Austria [6], infectious waste is used for limited contagious diseases (e.g., black death, anthrax, tuberculosis, etc.), while in others (e.g., Greece) all waste generated by patients is considered infectious. According to the World Health Organization, infectious waste is the waste type suspected to contain pathogens (bacteria, viruses, parasites or fungi) in sufficient concentration or quantity to cause disease in susceptible hosts [3]. Pathogens in infectious waste may 
enter the human body by a number of routes:

- Through a puncture, abrasion, or cut in the skin ;

- Through the mucous membrane ;

- By inhalation ;

- Ingestion.

The greatest risk due to infectious waste is the risk of needle stick injuries with needles, which can be the cause of hepatitis B, hepatitis C or HIV. Health care is a basic need for current and future generations [7]. The probability of infection due to needle prick is higher for hepatitis than for HIV [8].

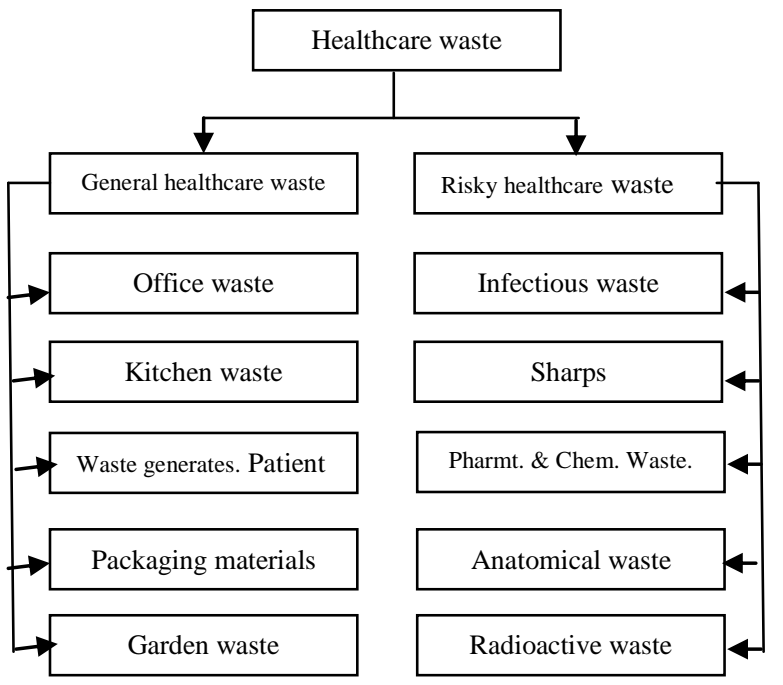

Fig. 1. Healthcare waste categories

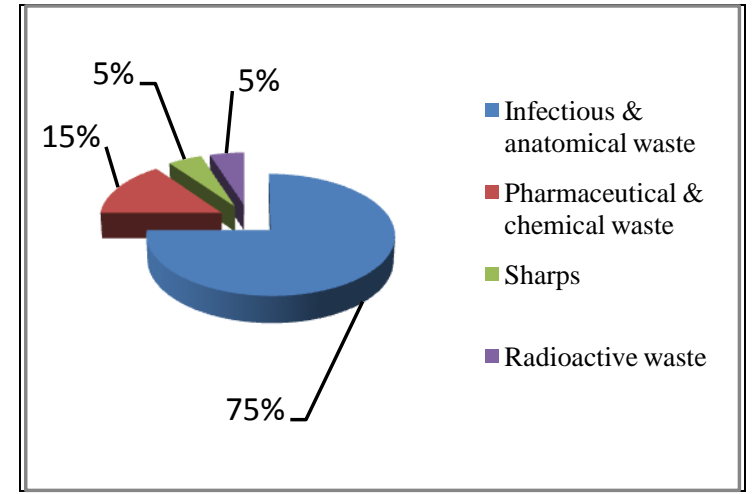

Fig. 2. Percentage of waste type per healthcare risk waste

\section{MATERIALS AND METHODS}

\section{A. Collection and Separation of $\mathrm{HCW}$ in the Hospital of Batna City}

The hospital of Batna city was opened in 1979 and the total number of beds is 635 , the percentage of beds in different services is shown in Fig. 3.

In the Hospital of Batna city, $\mathrm{HCW}$ is passing through a number of steps from its point of generation, through transport and treatment to its final disposal at a landfill for the HCGW and to the incinerator for RHCW. This so-called waste flow consists of the following:

- Generation of HCW (RHCW + GHCW);

- Segregation of HCW in GHCW and selected RHCW categories;

- Containerisation of HCW according to different categories;
- Intermediate storage of HCW;

- Internal collection and transport of HCW.

The RHCW were previously sorted into two components:

- Needles, broken glassware, ampoules, scalpel blades, lancets, syringes (yellow container),

- Gloves, bandages, catheters, bandages, plasters, tubes, medications, anatomical waste (red bag).

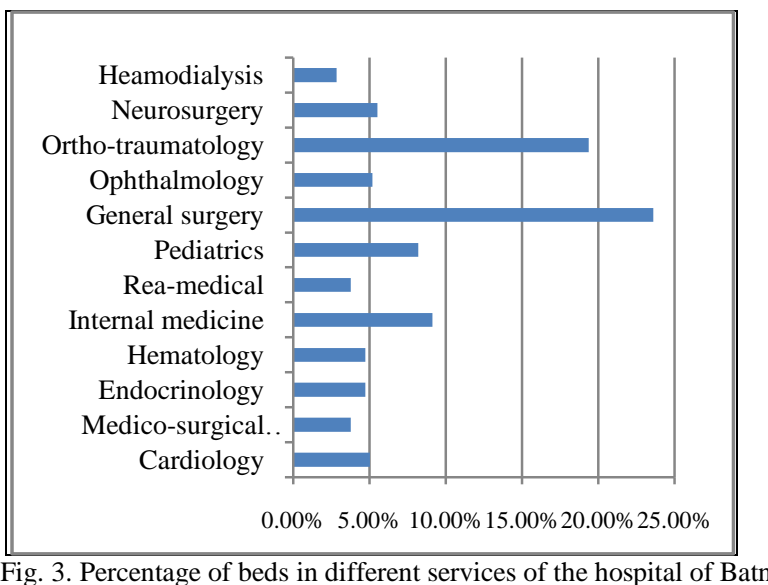

But For some services, there is still a lack for the collection and final disposal of medical wastes. Thus, the wastes are not properly segregated, collected and disposed, which may lead to a negative impact on public health and on the environment.

For our study, all of the wastes generated in the different services of the hospital were weighed every day during a period of one month. Containers and bags were weighed and recorded by the end of the working on each collection day. The quantity of RHCW generated by this hospital was about $1114 \mathrm{~kg} /$ day. The results indicated that the rate was 1.75 $\mathrm{kg} / \mathrm{bed} / \mathrm{day}$. This is higher than the national value of 0.72 $\mathrm{kg} / \mathrm{bed} /$ day [9]. RHCW quantities were higher in the service of Haemodialysis, General Surgery service and Endocrinology service (Fig. 4).

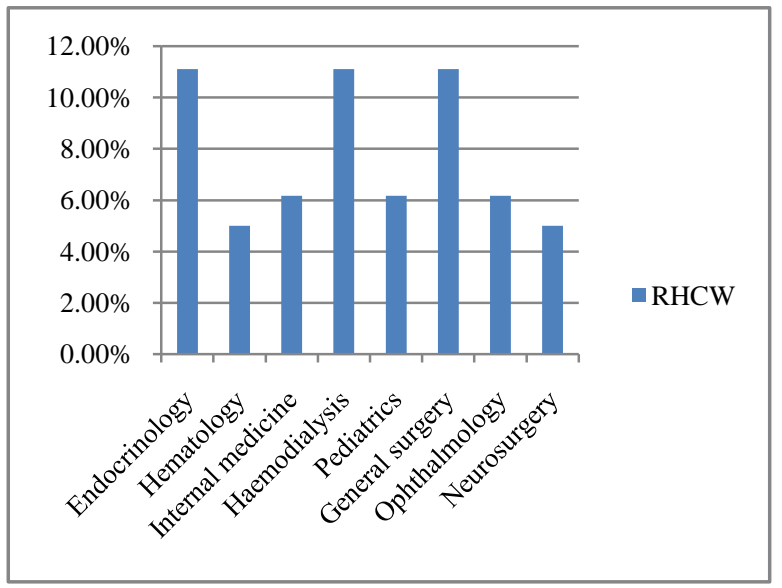

Fig. 4. Percentage of the higher production of RHCW in different services of the hospital of Batna city

\section{B. Description of Preliminary Hazard Analysis (PHA)}

Preliminary hazard analysis (PHA) is a semi-quantitative analysis that is performed to [10]:

- Identify all potential hazards and accidental events that may lead to an accident

- Rank the identified accidental events according to their severity 
- Identify required hazard controls and follow-up actions

TABLE I: RISK ASSESSMENT MATRIX

\begin{tabular}{|c|c|c|c|c|c|c|}
\hline \multirow{2}{*}{} & \multicolumn{5}{|c|}{ Hazard severity } \\
\cline { 2 - 7 } & $\begin{array}{c}\text { No effect } \\
(1)\end{array}$ & $\begin{array}{c}\text { Minor } \\
(2)\end{array}$ & $\begin{array}{c}\text { Major } \\
(3)\end{array}$ & $\begin{array}{c}\text { Hazardous } \\
(4)\end{array}$ & $\begin{array}{c}\text { Catastrophic } \\
(5)\end{array}$ \\
\hline \multirow{5}{*}{$\begin{array}{c}\text { Likelihood } \\
\text { of } \\
\text { occurrence }\end{array}$} & $\begin{array}{c}\text { Vnlikely } \\
(A)\end{array}$ & Low & Low & Low & Low & Medium \\
\cline { 2 - 7 } & $\begin{array}{c}\text { Unlikely } \\
(B)\end{array}$ & Low & Low & Low & Medium & Medium \\
\cline { 2 - 7 } & $\begin{array}{c}\text { Possible } \\
(C)\end{array}$ & Low & Low & $\begin{array}{c}\text { Mediu } \\
\mathrm{m}\end{array}$ & Medium & High \\
\cline { 2 - 7 } & $\begin{array}{c}\text { Likely } \\
(D)\end{array}$ & Low & $\begin{array}{c}\text { Mediu } \\
\mathrm{m}\end{array}$ & $\begin{array}{c}\text { Mediu } \\
\mathrm{m}\end{array}$ & High & High \\
\cline { 2 - 7 } & $\begin{array}{c}\text { Very } \\
\text { Likely } \\
(E)\end{array}$ & Low & $\begin{array}{c}\text { Mediu } \\
\mathrm{m}\end{array}$ & High & High & High \\
\hline
\end{tabular}

The objective of the application of the Preliminary Hazard Analysis (PHA) is to identify and analyze the hazards and risks associated with all processes involved with the handling and transporting of HCRW, to assess the finding against the risk criteria and identify opportunities for risk reduction, and make recommendations as appropriate.

TABLE II: SEVERITY OF CONSEQUENCE CRITERIA

\begin{tabular}{|l|l|}
\hline No effect & Has no effect on health \\
\hline Minor & Minor injury \\
\hline Major & Injury \\
\hline Hazardous & Serious or fatal injury \\
\hline catastrophic & death \\
\hline
\end{tabular}

TABLE III: PRELIMINARY HAZARD ANALYSIS APPLIED FOR RHCW

\begin{tabular}{|c|c|c|c|c|c|c|}
\hline HCRW & $\begin{array}{l}\text { Potential hazards } \\
\text { elements }\end{array}$ & $\begin{array}{l}\text { Probable } \\
\text { causes }\end{array}$ & Accidental events & Preventive actions & Likelihood & Severity \\
\hline Infectious waste & $\begin{array}{l}\text { Blood from patients } \\
\text { contaminated. } \\
\text { Faeces from patients } \\
\text { infected. } \\
\text { Respiratory tract } \\
\text { secretions from patients } \\
\text { infected. }\end{array}$ & $\begin{array}{l}\text { Contact } \\
\text { Inhalation }\end{array}$ & $\begin{array}{l}\text { Infection (HIV, viral } \\
\text { hepatitis, brucellosis, } \\
\text { typhoid fever, } \\
\text { enteritis, cholera, } \\
\text { TB, anthrax, rabies, } \\
\text { poliomyelitis, etc...). }\end{array}$ & $\begin{array}{l}\text { Collected in bags or containers for } \\
\text { infectious waste and should be } \\
\text { marked with the international } \\
\text { infectious substance symbol . } \\
\text { Use of appropriate Personnel } \\
\text { protective equipement. } \\
\text { Develop written work and emergency } \\
\text { procedures. }\end{array}$ & $\mathrm{C}$ & 5 \\
\hline Sharps & $\begin{array}{l}\text { Needles, } \\
\text { Broken glassware, } \\
\text { Ampoules, Scalpel } \\
\text { blades, Lancets, } \\
\text { Vials without content }\end{array}$ & $\begin{array}{l}\text { Punctures } \\
\text { Cuts } \\
\text { Infect the } \\
\text { wounds }\end{array}$ & $\begin{array}{l}\text { Injury } \\
\text { Infection }\end{array}$ & $\begin{array}{l}\text { Collected in rigid containers. } \\
\text { Containers should be puncture-proof } \\
\text { and fitted with covers. } \\
\text { Use of appropriate Personnel } \\
\text { protective equipement. } \\
\text { Develop written work and emergency } \\
\text { procedures. }\end{array}$ & $\mathrm{D}$ & 5 \\
\hline $\begin{array}{l}\text { Pharmaceutical \& } \\
\text { chemical waste }\end{array}$ & $\begin{array}{l}\text { Chemical or } \\
\text { pharmaceutical } \\
\text { substance (flammable, } \\
\text { corrosive, toxic) }\end{array}$ & $\begin{array}{l}\text { Contact } \\
\text { Absorption } \\
\text { Inhalation } \\
\text { Ingestion }\end{array}$ & $\begin{array}{l}\text { Intoxication } \\
\text { Injuries and burns }\end{array}$ & $\begin{array}{l}\text { Collected together with infectious } \\
\text { waste. } \\
\text { Other pharmaceutical waste of the } \\
\text { risk of contaminating should be } \\
\text { deposited in the correct container at } \\
\text { the point of production. } \\
\text { Chemical waste should be packed in } \\
\text { chemical resistant } \\
\text { containers and sent to specialized } \\
\text { treatment facilities. } \\
\text { Use of appropriate Personnel } \\
\text { protective equipement. } \\
\text { Develop written work and emergency } \\
\text { procedures. }\end{array}$ & $\mathrm{B}$ & 4 \\
\hline $\begin{array}{l}\text { Human } \\
\text { anatomical waste }\end{array}$ & $\begin{array}{l}\text { Tissue waste } \\
\text { Removed organs } \\
\text { Amputated body parts } \\
\text { Placentas, etc... }\end{array}$ & Contact & Infection & $\begin{array}{l}\text { Collected in green bags. } \\
\text { Use of appropriate Personnel } \\
\text { protective equipement. } \\
\text { Develop written work and emergency } \\
\text { procedures. }\end{array}$ & $\mathrm{D}$ & 4 \\
\hline Radioactive waste & $\begin{array}{l}\text { Solid, liquid and } \\
\text { gaseous waste } \\
\text { contaminated with } \\
\text { radionuclides }\end{array}$ & Contact & $\begin{array}{l}\text { Headache, dizziness, } \\
\text { and vomiting. } \\
\text { Irradiation }\end{array}$ & $\begin{array}{l}\text { Should be placed in yellow } \\
\text { containers, sealed, marked and } \\
\text { indicated with the international } \\
\text { radioactive symbol. } \\
\text { Use of appropriate Personnel } \\
\text { protective equipement. } \\
\text { Develop written work and emergency } \\
\text { procedures. }\end{array}$ & $\mathrm{B}$ & 5 \\
\hline
\end{tabular}


The risk is then determined from the Risk Assessment Matrix shown in Table I. The intersection of Severity (Table II) and Likelihood determines the level of risk acceptability on the matrix. For example, a "5 D" is of Catastrophic Severity (1), but Likely (D) Likelihood; therefore, the risk is high.

\section{RESULTS AND DISCUSSION}

Wastes are segregated according to their characteristics, mainly into the following categories: infectious wastes, sharps, Pharmaceutical \& chemical wastes, Human anatomical waste and Radioactive wastes. Risk assessment is presented in Table III. This identifies hazards, analysis and evaluation of risk related to exposure to risky healthcare waste (RHCW).

The results of the preliminary hazard analysis and according to the Risk Assessment Matrix, sharps, infectious waste and Human anatomical waste are in the area of high risks. Sharps are the RHCW items that represent the most acute potential hazards to health. Sharps may not only cause cuts and punctures but also infect these wounds if they are contaminated with pathogens. Because of this double risk of injury and disease transmission, sharps are considered as a very hazardous waste class. The principal concerns are infections that may be transmitted by subcutaneous introduction of the causative agent. Hypodermic needles constitute an important part of the sharps waste category and are particularly hazardous because they are often contaminated with patients' blood.

It was recorded, especially in services where there is a lack in segregated, waste that many cases of infection with a wide variety of pathogens have resulted from exposure to improperly managed healthcare wastes in the hospital of Batna. Health care workers, particularly nurses and wastemanagement operators are the most persons at greatest risk of infection through injuries from contaminated sharps.

High risks associated with other types of healthcare waste, in particular infectious waste and anatomical waste may be significant. In the meantime, precautionary measures should be taken

Thus, all staff that handles HCW must be trained to deal with injuries and exposures. A program that would prescribe the actions taken in the event of injury or exposure to a hazardous substance should be developed. Mainly, all personnel who are directly involved in the handling of potentially hazardous health care waste must be provided with adequate protection from the hazardous associated with it.

\section{CONCLUSION}

A comprehensive healthcare waste management plan is the key ingredient to a successful waste management within a health care facility. When, wastes are not properly segregated, collected and disposed, this may lead to a negative impact on public health and on the environment. Despite the efforts for the management of wastes, the current system of healthcare waste management in the hospital of Batna city is under development and is in dire need of immediate attention and improvement. The use of Preliminary hazard analysis (PHA) allowed us to identify all potential hazards and accidental events that may lead to an accident, Rank the identified accidental events according to their severity and identify required hazard controls and follow-up actions. Also, a risk assessment for the healthcare waste in the Hospital of Batna City was determined.

Further research is necessary to increase knowledge of the risk level for contamination of the exposed population by digestive, respiratory, and percutaneous routes and the growth and survival of pathogens in waste during storage.

\section{ACKNOWLEDGMENT}

The authors wish to thank all of the members of the healthcare institutions that participated in the survey.

The authors would like to express thanks to Mr Sadouk of Health Department. Finally, the authors would also like to extend their most sincere appreciation to the Epidemiology service for supporting this study and for their continued collaboration in the management of health care wastes in Batna.

\section{REFERENCES}

[1] E. Shinee, E. Gombojav, A. Nishimura, N. Hamajima, and K. Ito "Healthcare waste management in the capital city of Mongolia," Waste Management, vol. 28, issue 2, pp. 435-441, 2008.

[2] D. Komilis, N. Katsafaros and P. Vassilopoulos, "Hazardous medical waste generation in Greece: case studies from medical facilities in Attica and from a small insular hospital," Waste Management and Research, vol. 29, pp. 807-14. 2011

[3] A. Pruss, E. Giroult and P. Rushbrook, "Safe Management of Wastes from Healthcare Activities," WHO, Geneva, 1999.

[4] World Health Organization (WHO), "Management of solid healthcare waste at primary health-care centres: a decision-making guide," WHO. 2005.

[5] A. Graikos, E. Voudrias, A. Papazachariou, N. Iosifidis and M. Kalpakidou, "Composition and production rate of medical waste from a small producer in Greece," Waste Management, vol. 30, pp.16831689, January 2010

[6] S. Mahnik and G. Horinek,, "Management of hazardous waste in medical institutions in Austria," in Proceedings of First Conference on Hazardous Waste Management, Chania-Crete, Greece, pp.1-3 October 2008.

[7] United Nations Development Programme (UNDP). (2005). Human Development Report. [Online] Available: http:// hdr.undp.org/reports/global/2005/.

[8] A. Kane, J. Lloyd, M. Zaffran, L. Simonsen, and J. Kane, "Transmission of hepatitis B, hepatitis $\mathrm{C}$, and human immunodeficiency viruses through unsafe injections in the developing world: Model based regional estimates," Bulletin of the World Health Organization, vol. 77, no. 10, pp. 801-807. 1999.

[9] Z. Z. Bendjoudi, F. Taleb, F. Abdelmalek and A. Addou, "Healthcare waste management in Algeria and Mostaganem department," Waste Management, vol. 29, no. 4, pp. 1383-7, January 2009.

[10] M. Rausand, "Preliminary Hazard Analysis," System Reliability Theory (2nd ed), Wiley, 2004.

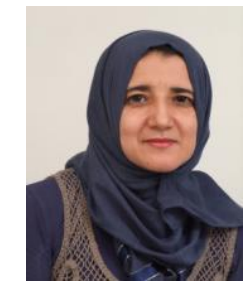

L. Sefouhi is from Batna, Algeria. She was working as an engineer at University Hadj Lakhder Batna Algeria, and magister at University Hadj Lakhder Batna Algeria, She is now studying as a $\mathrm{PhD}$ student at University Hadj Lakhder Batna Algeria, Her field of study are Environment, safety and health

She is currently also working as a Laboratory engineer and assistant master in University Hadj

Lakhder Batna, Algeria. 